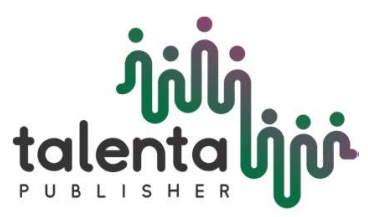

\title{
Competitive Advantage of Broiler Production in District Mansehra
}

\author{
Fida Muhammad Khan, Ghaffar Ali, Khuram Nawaz Sadozai, and Noor P \\ Khan
}

Department of Agricultural \& Applied Economics, Faculty of Rural Social Sciences, The University of Agriculture, Peshawar-Pakistan

\begin{abstract}
Poultry is an important sub sector of livestock and is ahead of all other sub sectors in economic growth. Broilers production is a specialized branch of poultry farming. This research was conducted in Mansehra is the region where considerable amount of commercial broiler production takes place. The region of the study has a high concentration of commercial activities, infrastructural facilities like veterinary care as well as climate that favor the production and marketing of poultry meat products. This research was conducted in nine villages of district Mansehra namely Kotli Pain, KotliBala, Kheil, Tanda, Bafa, Chatar Plain, Ahl, Batal and Mongandawraha. The purpose of the research was to analyze the competitive advantage of broiler farming. There were 276 broiler farms in District Mansehra. Simple Random Sampling Technique was used for data collection from 70 respondents. Average total cost of production was found Rs. 738238.11 having average farm size of 3605 broilers. Feed and one day old chick costs constitute $90.01 \%$ of the total cost. Average expenditure on production per broiler was Rs. 220.20 having net profit per broiler of Rs. 24.11.Based on Porter study (1990), average variable cost (C) was used as a proxy for competitive advantage. Results of regression analysis show that the main factors that significantly affect competitive advantage of broiler farming in the study area was feed cost, day old chick cost, labor and medication cost while capacity utilization and extension service contacts negatively and significantly affect cost. It means that reducing the above mentioned costs and using installed capacity and extension service contacts will reduce production cost and will promote competitive advantage of broiler production. Broiler production should be encouraged through better feed management practices and also by feeding broilers with nutritious feed. Broiler farmers should be encouraged to fully use their installed capacity of their farm.
\end{abstract}

Keywords: broiler, competitive advantage, economic analysis, proportional allocation, regression, simple random sampling technique, total cost

Received 14 July 2018 | Revised 04 August 2018 | Accepted 20 August 2018

\section{Introduction}

The poultry sector in Pakistan is one of the substantial sub-sectors of agriculture realm. This sector employees 1.5 million labor force of Pakistan as illustrated by Pakistan Economic Survey, 2017. The contribution of Poultry meat is 31 percent to the total meat production in the

\footnotetext{
*Corresponding author at: Department of Agricultural \& Applied Economics, Faculty of Rural Social Sciences, The University of Agriculture, Peshawar-Pakistan

E-mail address: fidaeconomist@gmail.com
} 
country [1]. Correspondingly this sector has contributed 1.4 percent to Pakistan's GDP during year 2016-17. However, its value added contribution to agriculture and live stock was ranked as 7.1 and 12.2 percent respectively [1].

Chickens are an important domestic fowl worldwide, especially for nutritious flesh as a source of food [2]. Broiler meat is deemed as one of the cheapest source of animal proteins consumed by an individual in Pakistan. The average price of per kilogram of broiler meat is about Rs.142.10 [3], which is highly economic as compared to other sources of meat. Poultry produced in Pakistan is being developed through two management systems namely commercial farming and rural poultry farming. The commercial poultry farming sector is a classic example of private sector enterprise with a phenomenal growth of 15-20 percent per annum. Modern poultry farming has a special importance for countries such as Pakistan. On the other hand poultry production is considered to be one of the most economical and efficient systems of producing animal protein foods. Poultry meat production was about 1,276,000 tonnes in 201617 [4]. This sector played a pivotal role in bridging the gap between supply and requirement of animal protein [5].

The significance of poultry farming cannot be ignored as it can provide a paved way to the poultry producers to fetch lucrative profit and can also be considered as a notable source of food to the consumer. Therefore, this research endeavor is designed to address the competitive advantage of broiler production in district Mansehra. Specific objectives of this research study were 1) to identify the factors that affects the cost of broiler farming in the study area and 2) to identify constraints and problems faced by poultry farmers.

\section{Materials and Methods}

This research was based on farm level data which was collected from commercial broiler agribusinesses in Mansehra of Khyber Pakhtunkhwa. This region is considered as high broiler production region as well as is famous for having high concentration of commercial broiler production activities, infrastructural facilities like veterinary care and climate that favor the production and marketing of poultry meat products [6].

\subsection{Sampling Design and Sample Size}

Though the sample frame was not available therefore, a list of poultry farmers was constructed by conducting the pilot survey and it was observed that approximately there were 276 broiler farms in Mansehra district. A sample size of 70 broiler farms ( $25 \%$ of population) was selected through Simple Random Sampling Technique by using the following formula [7].

$$
\mathrm{n}_{\mathrm{i}}=\mathrm{n}\left(\mathrm{N}_{\mathrm{i}} / \mathrm{N}\right)
$$

Where: 
$\mathrm{n}_{\mathrm{i}}=$ Sample of broiler farms to be taken from $\mathrm{i}^{\text {th }}$ village.

$\mathrm{n}=$ Total size of sample, $\mathrm{N}_{\mathrm{i}}=$ Total broiler farms in $\mathrm{i}^{\text {th }}$ village.

$\mathrm{N}=$ Total population of broiler farmers in the study area.

\subsection{Analytical Framework}

The analytical framework developed for this study was based on the one proposed by Porter [8]. According to Porter, there are many factors which affect the competition among firms in an environment. These factors include demand conditions, firm strategy, factor conditions, related and supporting industries, arrangement and competition. According to Porter [9] competitive advantage is created when a firm efficiently utilizes its resources as well as capabilities to minimize its cost of production. The broiler production depends upon the use of resources such as feed and day old chick. So the competitive advantage is determined by quality and quantity of feed and also by the cost of these inputs. Similarly the factor condition and production cost is also determined by these inputs that is feed and day old chick cost. Hence the analytical framework for the study was based on the fact that the competitive advantage is created through a lower cost of production per unit than its competitors, which is determined by cost of productive inputs as well as operational activities. For this reason average variable cost (C) was used as a proxy for competitive advantage, was modeled to be influenced by explanatory variables such as broiler output produced at market age, cost of inputs per bird as well as extension service contacts, market age of broilers and capacity utilization of farm structure. The general form of this cost/competitive advantage model is similar to one proposed by Dziwornu [10] and is specified as:

$$
C_{i}=f(Y, X, B)+\epsilon_{i}
$$

Where $C$ represents average variable cost per broiler (the weight of which varies from farm to farm and is sold on per kg basis), $\mathrm{Y}$ is output, $\mathrm{X}$ is a vector of independent input costs and other fixed costs assume to influence cost/competitive advantage, $\beta$ are coefficients to be estimated, $i$ represents the farm surveyed and $\boldsymbol{\epsilon}_{i}$ represents the error term. The cost/competitive advantage regression model used for the study is specified as:

\section{$\ln C_{i}=\beta_{0}+\beta_{1} \ln Y_{i}+\beta_{2} \ln C D_{i}+\beta_{3} \ln C F_{i}+\beta_{4} \ln C L_{i}+\beta_{5} \ln C M_{i}+\beta_{6} \ln D K_{i}+\beta_{7} \ln E C_{i}+\beta_{8} \ln M A g e_{i}+\beta_{9} C U t_{i}+e_{i}$}

The model used is in $\ln$ form in order to get precised results. In the model ln represents $=$ Natural logarithm, $C i=$ Competitive advantage of broiler agribusiness, $\mathrm{Y}=$ Number of broilers produced at market age in a batch in per broiler farm, $\mathrm{CD}=$ per unit cost of one day old chick, $\mathrm{CF}=$ Feed cost per bird, $\mathrm{CL}=$ Labor cost per bird, $\mathrm{CM}=$ Cost of medications and vaccines per bird, $\mathrm{DK}=$ Cost of capital input per bird, $\mathrm{EC}=$ Extension service contact measured as the number of extension contacts broiler agribusiness had in a batch, MAge $=$ Market age of broiler measured as the deviation from the standard 40 days for a broiler to ready from the market, $\mathrm{CU}$ 
$=$ Proportion of installed capacity of broiler farm utilized by the producer, $\beta i=$ Parameters to be estimated and measures the percentage changes in the dependent variable (cost), $\epsilon_{i}=$ error term.

\section{Results and Discussion}

The major findings of this research study are illustrated in tabulated form in the given section. The interpretation of the results and their discussion is also underscored to compare the results with previous research studies.

\subsection{Descriptive Statistics}

The descriptive statistics of the major variables is illustrated in Table 1. The range of number of day old chick was reported 700 to 13000 with mean of 3605 . The minimum poultry feed used was $7500 \mathrm{kgs}$ and maximum was $18250 \mathrm{kgs}$ with the mean value of $11609 \mathrm{kgs}$. To get the healthy and diseased free broilers vaccination was done to the chicks by the producers whose application was 4 to 6 times during their growth cycle, having mean number of 4.39. Labor plays a pivotal role in various poultry farm management whose range was reported as minimum number of labor used was 1.00 and maximum was 5.00 with a mean value of 1.99 (round off to 2 ). The cost of capital input was measured as the depreciation value of farm structure and equipment and was hypothesized to have a positive sign. The mean cost on capital inputs was Rs. 1085.18 with a minimum cost of Rs. 756 and maximum cost of 2492.30 having standard deviation of 433.27. This Table also reveals the descriptive statistics of other poultry farm practices such as number of contacts with Extension experts, number of broilers produced in a batch and capacity utilization.

Table 1. Descriptive Statistics of Major Variables

\begin{tabular}{lccccc}
\hline \multicolumn{1}{c}{ Variable } & Unit & Min. & Max. & Mean & Std. Dev \\
\hline Day-old chicks & No & 700 & 13000 & 3605 & 2686 \\
Feed & $\mathrm{Kg}$ & 7500 & 18250 & 11609 & 3714 \\
Medication & No & 04 & 06 & 4.39 & 3.95 \\
Labor & No & 01 & 05 & 1.99 & 1.39 \\
Capital inputs & Rs & 756 & 2492.3 & 1085.18 & 433.27 \\
Extension service & No & 2.00 & 6.00 & 4.62 & 1.06 \\
Output & No & 625 & 12100 & 3352.65 & 2540 \\
Capacity utilization & $\%$ & 0.28 & 1.00 & 0.87 & 0.15 \\
\hline
\end{tabular}

Source: Calculated from survey data (2015-16).

\subsection{Average Cost of Production of Broilers}

The ultimate goal of the producers is to fetch reasonable profit from any business. Profitable businesses are the key indicator for escalating the economy. Therefore, to estimate the cost and net returns can provide the new avenues for the concerned stakeholders and policy makers. Therefore, an average production cost of broilers is estimated and demonstrated in Table 1. The 
total cost of production computed for average broiler farm size (consisting of 3605 broilers) in the study area was found as Rs. 738238.11. In addition, an average cost of feed, day old chick and labor was estimated as Rs. 529486.49 (71.72 \%), Rs. 142433.55 (19.29 \%) and Rs. $20184.29(2.73 \%)$ respectively. The other poultry farm operations and their cost are also presented in the Table 1.

Table 2. Average Cost of Production of Broilers

\begin{tabular}{lcrrrc}
\hline \multicolumn{1}{c}{ Variable } & Units & Quantity & Unit Cost & Total Cost & Percentage \\
\hline Day Old Chicks & No & 3605.00 & 39.51 & 142433.55 & 19.29 \\
Feed & Kg & 11609.00 & 45.61 & 529486.49 & 71.72 \\
Vaccination & No & 4.39 & 4551.93 & 19982.97 & 2.71 \\
Total Labor & No & 1.99 & 10142.86 & 20184.29 & 2.73 \\
Electricity Bills & Rs & 2.00 & 3347.86 & 6695.72 & 0.91 \\
Litter & Bags & 26.03 & 321.64 & 8372.29 & 1.13 \\
TVC & Rs & & & 727155.31 & \\
Rent of Building & Rs & & & 9997.62 & 1.35 \\
Equipment & Rs & & & 1085.18 & 0.15 \\
Total Fixed Cost & Rs & & & 11082.80 & \\
Total Cost & Rs & & & 738238.11 & \\
\hline Source: Calculed & & & & & \\
\hline
\end{tabular}

Source: Calculated from survey data (2015-16)

\subsection{Net Revenues of Broiler Farms}

One of the predominant aims of the producer is to surge their net revenues from their business. This research study has estimated average net-revenues of broiler farms whose average flock size was 3605 broilers. The average gross revenues of the poultry producers were computed by summing the revenue generated from broilers, manure and empty bags. It was observed that revenue generated from broiler had substantial contribution to total revenue and was calculated as Rs. 809899.66 with an average weight of $1.7 \mathrm{~kg}$ per broiler and unit price of Rs. 142.10 per kilogram. While the revenue estimated from manure and empty bags with minor contribution to gross revenue was reported as Rs. 7072.73 and Rs. 2122.80 respectively. These revenues from three different poultry outcomes have provided the gross revenue as Rs. 819095.19. Simultaneously, the total cost of production incurred by the poultry producer was also estimated and was reported as Rs. 738238.11. Hence, the net-revenue was obtained by subtracting total cost from gross revenue which was found Rs.80857.07 per mentioned flock size.

Table 3. Average Net Revenue of Broiler Farms

\begin{tabular}{lcrrr}
\hline \multicolumn{1}{c}{ Particulars } & Unit & Amount & $\begin{array}{c}\text { Rate } \\
\text { (Rupees/unit) }\end{array}$ & $\begin{array}{r}\text { Total Value } \\
\text { (In Rupees) }\end{array}$ \\
\hline Broiler & No & $3352.65^{*}$ & 142.10 & 809899.66 \\
Manure & Trolley & 4.18 & 1692.04 & 7072.73 \\
Empty Bags & No & 232.00 & 9.15 & 2122.80 \\
Gross Revenue & Rs & & & 819095.19 \\
TVC & Rs & & & 727155.31 \\
TFC & Rs & & & 11082.80 \\
TC & Rs & & & 738238.11 \\
Net Revenue & Rs & & & 80857.07 \\
\hline Soure: Calclat
\end{tabular}

Source: Calculated from survey Data, (2015-16). *Average weight of broiler $=1.7 \mathrm{~kg}$ 


\subsection{Model Adequacy Tests}

\subsubsection{Jorque-Bera test for normality}

The Jorque-Bera test of normality is an asymptotic, or large sample, test. This test first calculates the skewness and kurtosis. According to Gujarati [11] if the value of JB test is greater than 0.05 then it means that data is normally distributed. The results of JB test for the data shows that the p-value was 0.1399 which was greater than 0.05 so we accept the null hypothesis of normality.

\subsubsection{Koenker-Basset (KB) test for heteroscedasticity}

As the nature of the research data is cross section, so one can expect heteroscedasticity problem in the data. To check the research data for the said problem Koenker-Basset (KB) test was used. $\mathrm{KB}$ test is based on squared residuals. The squared residuals were being regressed on the squared estimates of the regressand. The results of $\mathrm{KB}$ test shows that the t-statistic is insignificant which means that there is no heteroscedasticity in data so we can't reject the null hypothesis of homoscedasticity. The result of KB test is as follow.

Table 4. Results of KB test

\begin{tabular}{|c|c|c|c|c|c|}
\hline \multirow[t]{2}{*}{ Model } & \multicolumn{2}{|c|}{ Unstandardized Coefficients } & $\begin{array}{c}\text { Standadized } \\
\text { Coefficients }\end{array}$ & \multirow[t]{2}{*}{ t } & \multirow[t]{2}{*}{ Sig. } \\
\hline & B & Std.Error & Beta & & \\
\hline Constant & -.038 & .040 & & -.959 & .341 \\
\hline PRE2 & .004 & .003 & .157 & 1.310 & .195 \\
\hline
\end{tabular}

\subsubsection{Variance Inflation Factor (VIF) test for Multicollinearity}

Multicollinearity is another problem that one can expect in the data. Multicollinearity was detected by using VIF test. The greater the value of VIF will mean that more is the problem of multicollinearity. According to Gujarati if the mean value of VIF exceeds from 10 then there will be the problem of multicollinearity [11]. The results of VIF test for the data shows that the mean value of VIF was 3.50 which was less than 10 so we accept the null hypothesis that there is no problem of multicollinearity.

Table 5. Results of VIF Test

\begin{tabular}{|c|c|c|}
\hline Variable & VIF & Tolerance (1/VIF) \\
\hline Output & 11.52 & 0.87 \\
\hline Day old chick & 2.56 & 0.40 \\
\hline Labor & 6.75 & 0.15 \\
\hline Capital inputs & 3.41 & 0.29 \\
\hline Medication/Vaccination & 2.17 & 0.46 \\
\hline Capacity Utilization & 1.92 & 0.52 \\
\hline Feed & 1.08 & 0.92 \\
\hline Market age & 1.07 & 0.93 \\
\hline $\begin{array}{l}\text { Extension } \\
\text { contacts }\end{array}$ & 1.02 & 0.98 \\
\hline Mean VIF & 3.50 & \\
\hline
\end{tabular}

Source: Calculated from survey data (2015-16) . 


\subsubsection{Estimation of competitive advantage of broiler production}

\section{a. Estimation of competitive advantage}

Table 7 shows the results obtained from multi-regression model which was run for finding the competitive advantage of broiler farming using average cost as a proxy for competitive advantage. All the estimated parameters have the expected sign. The estimated parameters of costs items of day old chick, feed, medication/vaccination and labor are positive and significant at $5 \%$ level. The sign of capital inputs are positive but statistically insignificant at $5 \%$ level of significance. The results were accordance to Dziwornu [10]. The parameter estimates of capacity utilization and extension service contacts have negative sign and statistically significant at 5\% level. The same result was found by Zahir-ud-Din et al. [12] and Dziwornu [10] for capacity utilization. The result of extension service contact was similar to the work done by Ashagidigb [13] and Dziwornu [10]. This mean that the factors included in the model are statistically different from zero except capital inputs and are therefore important in explaining competitive advantage in broiler farming production. The estimated parameters represent percentage change in cost/competitive advantage of broiler production when explanatory variables change by one percent. Competitive advantage is created when a firm uses its capabilities and resources to achieve a lower cost structure [9]. Based on this, competitive advantage can be increased by reducing per unit cost of production. Thus reduction in explanatory variable having positive estimated parameter will result in decrease in per unit cost, hence will promote competitive advantage. On the other hand, increase in the explanatory variable having negative estimated parameter will reduce per unit cost and promotes competitive advantage. The estimated coefficient shows that a one percent increase in the cost of feed, day old chick, medication/vaccination and labor will increase cost by $0.282,0.213$, 0.261 and $0.208 \%$ respectively. This means that reducing the cost of mentioned inputs will lead to a significant decrease in the per unit variable cost of broiler production, hence will create competitive advantage of broiler farming in the study area. Although farmers through efficient use of inputs can minimize their cost. The negative coefficient of capacity utilization and contacts with extension service implies that broiler producers who utilizes more of their installed capacity and have more contacts with extension service will reduce their production cost. Those broiler farmers who use more of their installed capacity will spread their cost over larger output. It will reduce per unit cost, hence will promote competitive advantage. More extension service contacts will enhance broiler producers abilities in broiler production. With new information and technical know-how from the extension service contacts, broiler farmers will be able to adopt better and modern production methods to reduce production cost. This will result in competitive advantage of broiler farming in the study area.

The statistic results show that the F-value was 43.84 and the value of co-efficient of determination $\left(\mathrm{R}^{2}\right)$ was about 0.81 which means that $81 \%$ of variability in per unit variable cost 
has been explained by explanatory variables in the model. Indeed, the regressors in the cost/competitive advantage model explain cost/competitive advantage of broiler farming.

Table 6. Results of regression analysis

\begin{tabular}{lccc}
\hline \multicolumn{1}{c}{ Variables } & Co-efficient & $\begin{array}{c}\text { Standard } \\
\text { error }\end{array}$ & t-ratios \\
\hline Constant & 1.62 & 1.13 & 1.43 \\
Output & 0.07 & 0.03 & 2.84 \\
Day old chick & 0.21 & 0.07 & 3.09 \\
Feed & 0.28 & 0.07 & 4.03 \\
Labor & 0.21 & 0.07 & 2.85 \\
Medication/vaccinaton & 0.26 & 0.10 & 2.56 \\
Capital inputs & 0.17 & 0.22 & 0.77 \\
Extension service & -0.22 & 0.08 & -2.63 \\
Capacity utilization & -0.28 & 0.09 & -3.25 \\
F-value & 43.84 & & \\
R-square & 0.81 & & \\
Adj R-squared & 0.78 & & \\
\hline
\end{tabular}

Source: Calculated from survey data (2015-16)

\section{Conclusion and Recommendation}

\subsection{Conclusion}

The research was conducted in major broiler producing villages of district Mansehra. The purpose of the study was to determine the competitive advantage of broiler farming in the study area. The average age of respondents in the research data was 33.96 years with average education of 9.28 and average experience of 6.65 years. The average number of broilers was 3605. The total average cost of production was Rs. 738238.11. Feed and one day old chick costs constitute $90.01 \%$ of the total cost. The cost of production per broiler was Rs. 220.20. The average net revenue was Rs. 80857.07 with a mortality rate of 7.01 percent. The average weight was $1.7 \mathrm{~kg}$ and the revenue per broiler was Rs. 24.11.

The tests were run to see heteroscedasticity problem, multicollinearity problem and normality in the data used. KB test was used for heteroscedasticity problem which indicated that there was no heteroscedasticity problem in the data. The results of VIF test showed that there was no multicollinearity problem in the data and similarly Jorque-Berra result showed that the data was normally distributed.

The results of regression showed that day old chick, feed, labor and medication in the model are positive and significant at 5\% level while capacity utilization and extension service contacts is negative. Thus a positive parameter estimate indicates that reduction in explanatory factor will result in reduction in per unit cost, and thus promotes competitive advantage. Similarly a negative parameter estimate means that an increase in explanatory factor will result in reduction in per unit cost, and will also promote competitive advantage. The study revealed that decrease 
in day old chick cost, feed cost, labor cost and medication cost will promote competitive advantage in broiler production. An increase in capacity utilization and extension services will reduce production cost to promote the competitive advantage of broiler.

The study discovers that feed cost, one day-old chick cost, labor cost, as well as market age of broiler and capacity utilization are the main factors that significantly affect the competitive advantage of broilers in the study area. Reduction in cost of feed, one day-old chick cost, labor cost and market age at which broilers are ready for sale will promote the competitive advantage in broiler production. Similarly, increase in capacity utilization will significantly reduce production cost to promote the competitive advantage of broiler production.

\subsection{Recommendation}

Following recommendations are provided based upon the findings to enhance competitive advantage of broiler in desired area.

1. Broiler producers should be encouraged to increase the capacity utilization of their farm structures which will reduce the production cost.

2. Livestock extension institutions should provide training to farmers for improved and modern production techniques. This will decrease their cost of production and mortality rate.

3. Most of farmers complained about feed quality, so it is suggested that the government should ensure the quality feed to poultry industry.

\section{REFERENCES}

[1] Government of Pakistan, Report of the National Commission on Agriculture. Islambad: Ministry of Food, Agriculture and Cooperatives, 2017.

[2] Unang, "Profitability and Efficiency of the Broiler Industry in Tasikmalaya," Thesis, University of Siliwangi, Tasikmalaya, 2003.

[3] Government of Pakistan, Report of the National Commission on Agriculture. Islambad: Ministry of Food, Agriculture and Cooperatives, 2016.

[4] Government of Pakistan, Pakistan Economic Survey 2016-17. Islambad: Ministry of Finance, Revenue, Economic Affairs, Statistics and Privazation, 2017.

[5] S. Ahmad, T. Z. Chohan and I. Ali, "Economic analysis of poultry (broiler) production in Mirpur Azad Jammu Kashmir," Pakistan Journal of Life and Social Sciences, vol. 6, no. 1, pp. 4-9, 2008.

[6] SMEDA, Small and medium enterprise development authority ministry of industries and production. Islambad: Government of Pakistan, 2009.

[7] W. G. Cochran, Sampling Techniques $3^{\text {rd }}$ Edition. New York: John Wiley and Sons, 1977.

[8] M. E. Porter, The Competitive Advantage of Nations. Simon \& Schuster, 1990.

[9] M. E. Porter, Competitive Advantage: Creating and Sustaining Superior Performance. New York: Free Press, 1985.

[10] R. K. Dziwornu, "Econometric analysis of factors affecting competitive advantage of broiler agribusinesses in Ghana," Journal of Development and Agricultural Economics, vol. 6 , no. 2, pp. 87-93, 2013. 
[11] D. Gujarati, Basic Econometrics. New York: McGraw-Hill, 2003.

[12] M. F. Zahir-ud-Din, Status of broilers produced in swat. Pakistan: Livestock research for rural development, 2001.

[13] W. M. Ashadigbi, "Technical and Allocative efficiency of poultry egg producers in Nigeria," Agricultural Journal, pp. 124-130. 